\title{
Is the secondary thickening in palms always diffuse?
}

\author{
MARLI P. BOTÂNICO and VERONICA ANGYALOSSY \\ Departamento de Botânica, Instituto de Biociências, Universidade de São Paulo, \\ Rua do Matão, 277, 05508-090 São Paulo, SP, Brasil \\ Manuscript received on July 5, 2012; accepted for publication on April 15, 2013
}

\begin{abstract}
Unlike other arboreal monocotyledons, the secondary growth of palms has for the past 100 years been described as diffuse. Solely cell enlargement and random parenchyma divisions, without the activity of a meristem, characterize such growth. Some previous works of the early $20^{\text {th }}$ century have, however, mentioned the presence of a secondary meristem in the stems of palms, but this information was forgotten since then. Addressing to this question, we analysed palm stems of four species, with the aim to understand the possible presence of such secondary growth. We found that a meristematic band occurs between the cortex and the central cylinder and gives rise to new vascular bundles and parenchyma internally, producing parenchyma and fibres externally. It appears secondarily, i.e., it undergoes meristematic activity in the median and basal stem regions, far away from the apical region. In fact, a meristematic band is present and may be more common than currently believed, but uneasy to detect in certain palms for being restricted to specific regions of their stems. In conclusion, the diffuse secondary thickening is here shown not to be the only mechanism of secondary growth in palms. The presence of a meristem band in the stems of palms merits careful reconsideration.
\end{abstract}

Key words: aerial stem, meristematic band, palms, secondary growth, stem anatomy, subterranean stem.

\section{INTRODUCTION}

The growth in thickness of palm stems is known to be diffuse. In fact, the term "diffuse secondary thickening" was created by Schoute in 1912, who broadened with his work the understanding of growth in palm stems given by previous workers cited by him, such as De Bary (1877), Eichler(1866), Strasburger (1891), Kraus (1899), and Barsickow (1901) (see Schoute 1912, for complete references). The authors cited by Schoute (1912) claimed that the growth in thickness resulted from an increase in the volume of parenchyma cells, discarding any

Correspondence to: Marli Pereira Botânico

Email:marlibot@yahoo.com.br increase resulting from the formation of additional vascular bundles. Although Schoute accepted their concept, he broaded it by noting that the expanding parenchyma cells also divided, thereby increasing their numbers. Moreover, expansion of the parenchyma cells resulted in the enlargement on the intercellular spaces, further contributing to the over-all increase in stem diameter. The presence of such diffuse growth in palm stems has since been confirmed many times (Tomlinson 1960, 1961, 1990, Tomlinson and Zimmermann 1967, Waterhouse and Quinn 1978).

Some arborescent monocotyledons increase the thickness of their stems by a totally different 
process. In these plants there is a meristem known as the secondary thickening meristem. This lateral meristem consists of cells that divide bidirectionally, adding new vascular bundles (secondary vascular bundles) to the central cylinder, and new parenchyma cells to both the cortex and the central cylinder.

Comparing secondary growth in palms with that of other arborescent monocotyledons, such as Dracaena, Cordyline, Beaucarnea, raises an intriguing questions: Why do palms, which have representatives with similar habits, only show secondary growth by means of cell expansion and cell division? Are there no palm species that present other types of secondary growth besides what was reported do far?

Seeking to answer these questions we carried out a study in palm species with different types of stems: subterranean, short and arboreal stems, aiming to analyze how the secondary growth takes place in rather different plants. In this work we present the results of this study.

\section{MATERIALS AND METHODS}

We have studied stems of the following species: Attalea geraensis Barb. Rodr., Butia paraguayensis (Barb. Rodr.) L.H. Bailey (Figure 1A - B), Syagrus petraea (Mart.) Becc. (Figure 1C), and Syagrus romanzoffiana (Cham.) Glassman (Figure 1 D - F). These species belong to the subfamily Arecoideae, tribe Cocoseae (Baker et al. 2009), however Attalea geraensis Barb. Rodr. belongs to the subtribe Attaleinae, according Dransfield et al. (2005).

All botanic materials have been deposited in the Universidade de São Paulo Biosciences Institute's Herbarium (SPF). Table I has a list of the species collected according to the collector's number, stem height, stem type and stem portion sampled. In order to make developmental studies, young stems of Syagrus romanzoffiana ranging from 50 to $100 \mathrm{~cm}$ in height were sampled. In the short-stemmed palm Butia paraguayensis (Figure 1A) and Attalea geraensis the samples were taken from the median portion of the stem, comprising cortex and central cylinder, as shown in Figure

TABLE I

Studied species, collector data, stem characteristics and sampled stem region.

\begin{tabular}{|c|c|c|c|c|}
\hline Species & Collector & Hight & Stem Type & Sampled stem region \\
\hline \multirow{3}{*}{ Attalea geraensis } & MP Botânico 23 & $0.98 \mathrm{~m}$ & \multirow{3}{*}{ short } & \multirow{3}{*}{ median } \\
\hline & MP Botânico 24 & $1.00 \mathrm{~m}$ & & \\
\hline & MP Botânico 25 & $1.00 \mathrm{~m}$ & & \\
\hline \multirow{3}{*}{ Butia paraguayensis } & MP Botânico 6 & $1.00 \mathrm{~m}$ & \multirow{3}{*}{ short } & \multirow{3}{*}{ median } \\
\hline & MP Botânico 7 & $0.95 \mathrm{~m}$ & & \\
\hline & MP Botânico 8 & $0.98 \mathrm{~m}$ & & \\
\hline \multirow{3}{*}{ Syagrus petraea } & MP Botânico 20 & $0.60 \mathrm{~m}$ & \multirow{3}{*}{ subterranean } & \multirow{3}{*}{ median } \\
\hline & MP Botânico 21 & $0.80 \mathrm{~m}$ & & \\
\hline & MP Botânico 22 & $0.90 \mathrm{~m}$ & & \\
\hline \multirow{3}{*}{$\begin{array}{l}\text { Syagrus romanzoffiana } \\
\text { (adult) }\end{array}$} & MP Botânico 1 & $12.00 \mathrm{~m}$ & \multirow{3}{*}{ tree } & \multirow{3}{*}{$\begin{array}{c}1.30 \mathrm{~m} \\
\text { (breath height) }\end{array}$} \\
\hline & MP Botânico 2 & $10.00 \mathrm{~m}$ & & \\
\hline & MP Botânico 3 & $12.50 \mathrm{~m}$ & & \\
\hline \multirow{3}{*}{$\begin{array}{c}\text { Syagrus romanzoffiana } \\
\text { (young) }\end{array}$} & MP Botânico (planted) & $0.60 \mathrm{~m}$ & \multirow{3}{*}{ tree } & \multirow{3}{*}{ basal } \\
\hline & MP Botânico (planted) & $1.00 \mathrm{~m}$ & & \\
\hline & MP Botânico (planted) & $1.20 \mathrm{~m}$ & & \\
\hline
\end{tabular}


1B. In the case of Syagrus petraea (Figure 1C), its subterranean stem was rather short and, therefore, samples were taken from the whole diameter of the stem, making it possible to analyze the stem from center to periphery. In the species Syagrus romanzoffiana (juvenile and adult tree) (Figure $1 \mathrm{D}-\mathrm{F}$ ) the basal portion of the young stems was sampled, while in the adult a wedge shaped sample was taken at breast height, comprising the central and peripheral portions.
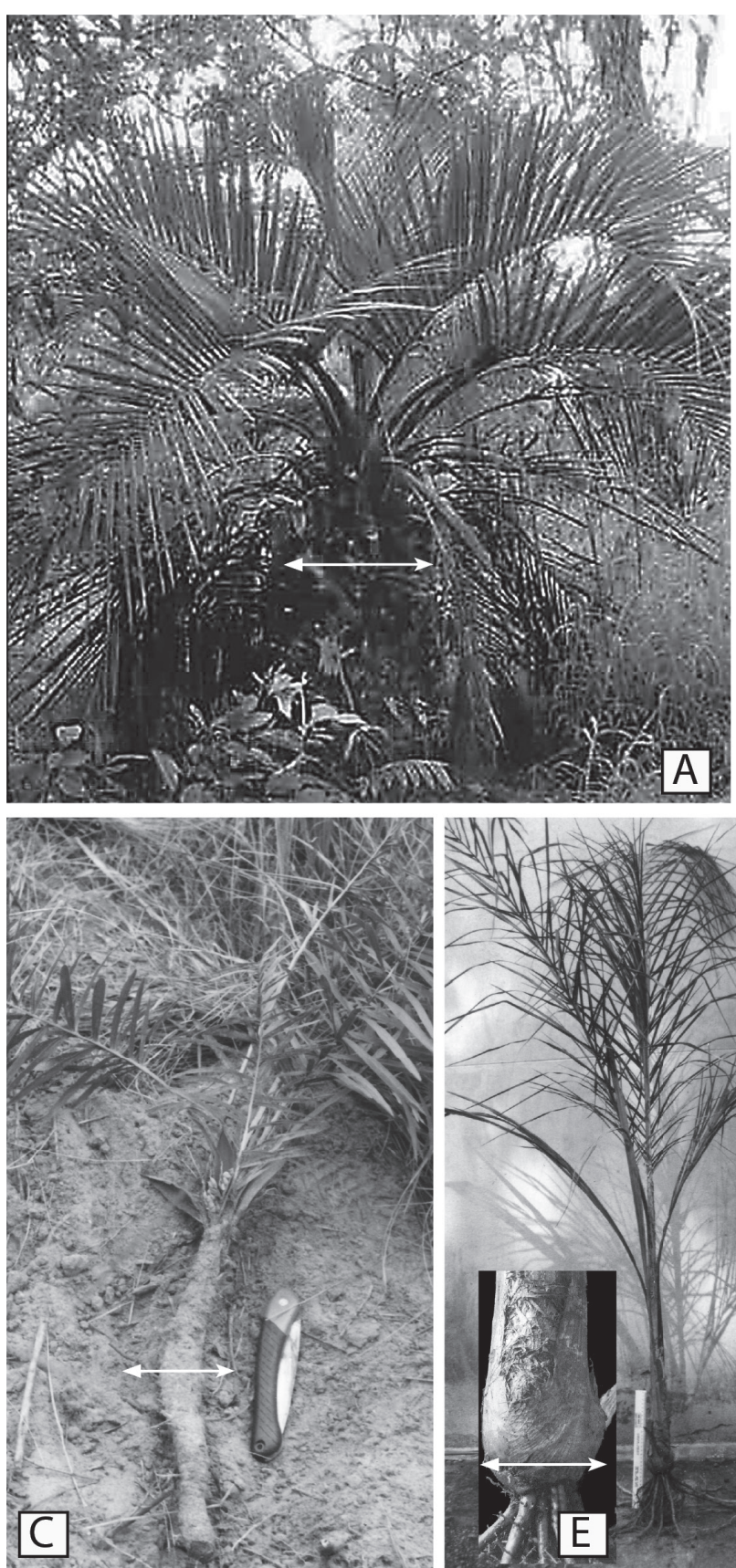

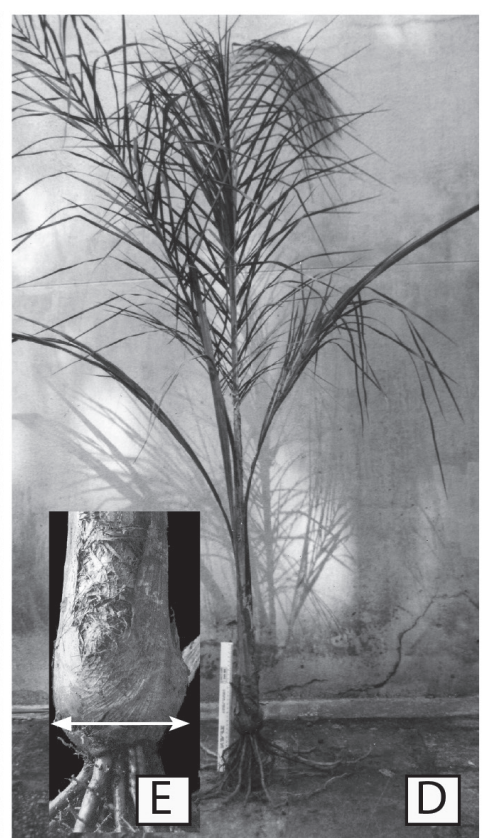

D
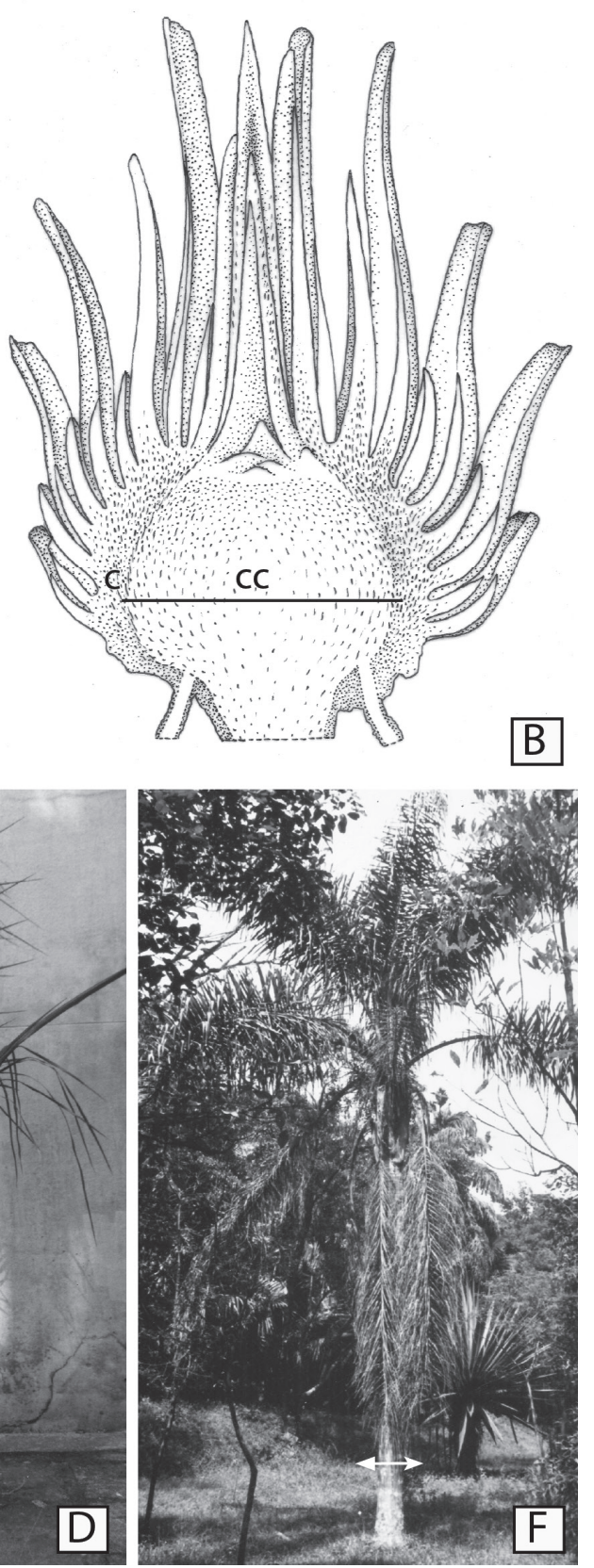

Figure 1 - Habit of the studied species. A - B. Butia paraguayensis. A. Short stem. B. Schematic diagram of the stem in longitudinal view. C: cortex, CC: central cylinder. C. Syagrus petraea. Subterranean stem. D - F. Syagrus romanzoffiana. D - E. Young plant. E. Detail of the basal portion of the stem. F. Adult plant. Arrows: sectioned portions of the stem. 
The samples were fixed in FAA $(10 \%$ formaldehyde, 5\% acetic acid, 70\% ethanol) according to Berlyn and Miksche (1976). After fixation, the adult samples were softened by boiling for approximately 20 minutes. Afterwards, the samples were embedded in polyethylene glycol 1500, according to Gerlach (1984), and sectioned on a Reichert sliding microtome, with the help of an adhesive tape (according to Barbosa et al. 2010). Transverse and longitudinal sections with thickness varying from 40 to $60 \mathrm{~mm}$ were made. The sections were double stained in $1 \%$ astra blue and $0.125 \%$ basic fuchsin (Kraus et al. 1998). The material was then dehydrated in an ethanol series, immersed in n-butyl acetate, and then mounted for permanent slides with a synthetic resin.

\section{RESULTS}

The stems of Attalea geraensis and Butia paraguayensis (short stem, Figure 1A - B), Syagrus petraea (subterranean stem, Figure 1C) and Syagrus romanzoffiana (juvenile and adult tree, Figure 1D $\mathrm{F})$ are anatomically organized in two regions: cortex and central cylinder (Figures 1B, 2A, D). The central cylinder is composed of a parenchymatous matrix in which primary vascular bundles are embedded (Figure 2D). The vascular bundles are collateral and consist of primary xylem and primary phloem, with a cap of fibers on the phloem side (Figure 2B - C). Two types of vascular bundles are found in the central cylinder: leaf traces with both protoxylem and metaxylem (Figure 2B), and axial bundles, containing only metaxylem (Figure 2C), The cortex consists of a parenchymatous matrix transversed by fiber strands and leaf traces that depart from the central cylinder (Figure 2A, D).

A meristematic band occurs between the cortex and the central cylinder at the median portion of the stem of Attalea geraensis, Butia paraguayensis and Syagrus petraea (Figures 2D, 4A-C), and the basal portion of the juvenile tree of Syagrus romanzoffiana (Figure 3A) giving rise to both new vascular bundles and parenchyma internally and parenchyma and fiber strands externally.

The meristematic band is composed of several layers of cells of primary walls that in transverse section may exhibit different forms (Figures 3A, 4C). When the band is active, its cells exhibit both anticlinal and periclinal divisions, with a prevalence of periclinal divisions (Figures 3A, 4C). Stem born root arises near this meristematic band, where a vascular plexus and parenchyma cells of the central cylinder converge to the apex of the root, as seen in Figure 2D.

As mentioned earlier, as a result of such meristematic activity, new vascular bundles and parenchyma cells (secondary internal parenchyma) are added to the central cylinder (Figures $3 \mathrm{~A}-\mathrm{B}$, 4A, C - D). Externally fiber strands and parenchyma cells (secondary external parenchyma) are added, contributing to the cortex, which will now form a secondary cortex (Figure 3A - C). Differentiating new vascular bundles and fiber strands can be seen bordering the meristematic band (Figures 3A-C, 4C), evidencing their origin.

The new vascular bundles (Figure 4A - C E), similar to the primary prior vascular bundles (Figure 4B), are collateral, with fibers bordering the phloem. As the stem ages and increases in diameter, the meristematic band produces additional radially arranged new vascular bundles. These bundles, with their fiber caps, are radially elongated and eventually anastomose (Figure 4A). As they are located very close one to the other, they compress the neighboring secondary parenchyma cells and form a compact tissue in this region.

Within the secondary cortex, the fiber strands that arise from the meristematic band may present different diameters. They increase in size as they mature, hence the larger strands are found farthest from the meristematic band (Figures 3A - B, 4A).

The meristematic band in the arboreal Syagrus romanzoffiana is restricted to the basal most portion of the stem. It is easily detected on the plantlets 

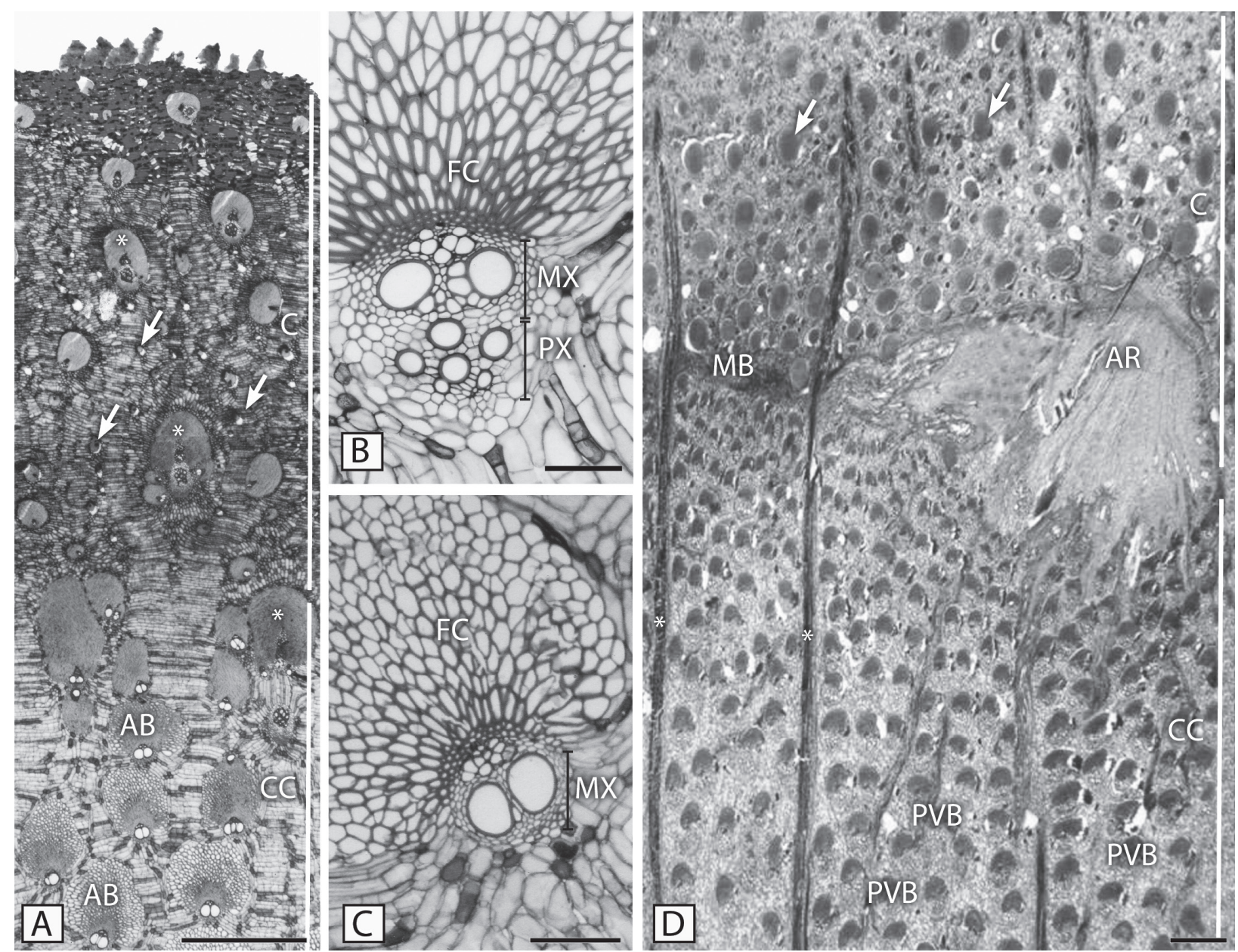

Figure 2 - A - D. Transverse sections of stem. A - C. Syagrus romanzoffiana. Adult tree. A. Cortical region (C), and central cylinder (CC) with leaf traces and axial bundles. B. Detail of a leaf trace. C. Detail of an axial bundle. D. Attalea geraensis. Short stem. Cortical region (C) and central cylinder (CC). Note the meristematic band (MB) and a stem borne root (AR). Arrows: fiber strands, Asterisks: leaf traces, AB: axial bundle, FC: fiber cap, MX: metaxylem; PVB: primary vascular bundle; PX: protoxylem. Scale bars: $10 \mu \mathrm{m}$ (A); $100 \mu \mathrm{m}$ (B); $50 \mu \mathrm{m}$ (C); $1 \mathrm{~m}$ (D).

(Figures 1E, 3A - C). In the adult stem (Figure 1F), on the other hand, no meristematic band can be detected at breast height (Figure 2A).

\section{DISCUSSION}

The analysis of the stem of four species of palms with different habits: subterranean, short and arboreal, has revealed a kind of growth in thickness that had not been reported in the literature in the past 100 years. The results observed in Attalea geraensis, Butia paraguayensis, Syagrus petraea and Syagrus romanzoffiana point to the fact that the meristematic band found in their stems appears secondarily, acting in the median and basal stem regions similar to that already reported secondary thickening meristem present in some other monocotyledonous species.

An extensive research done by Zimmermann and Tomlinson on palm stem anatomy is highlighted in the literature (Zimmermann and Tomlinson 1965, 1967, 1968, 1974, Tomlinson and Zimmernmann 1966, Zimmermann et al. 1982, Tomlinson et al. 2001, Tomlinson and Spangler 2002, Tomlinson 2006). Palms possess a lateral meristem near the stem 

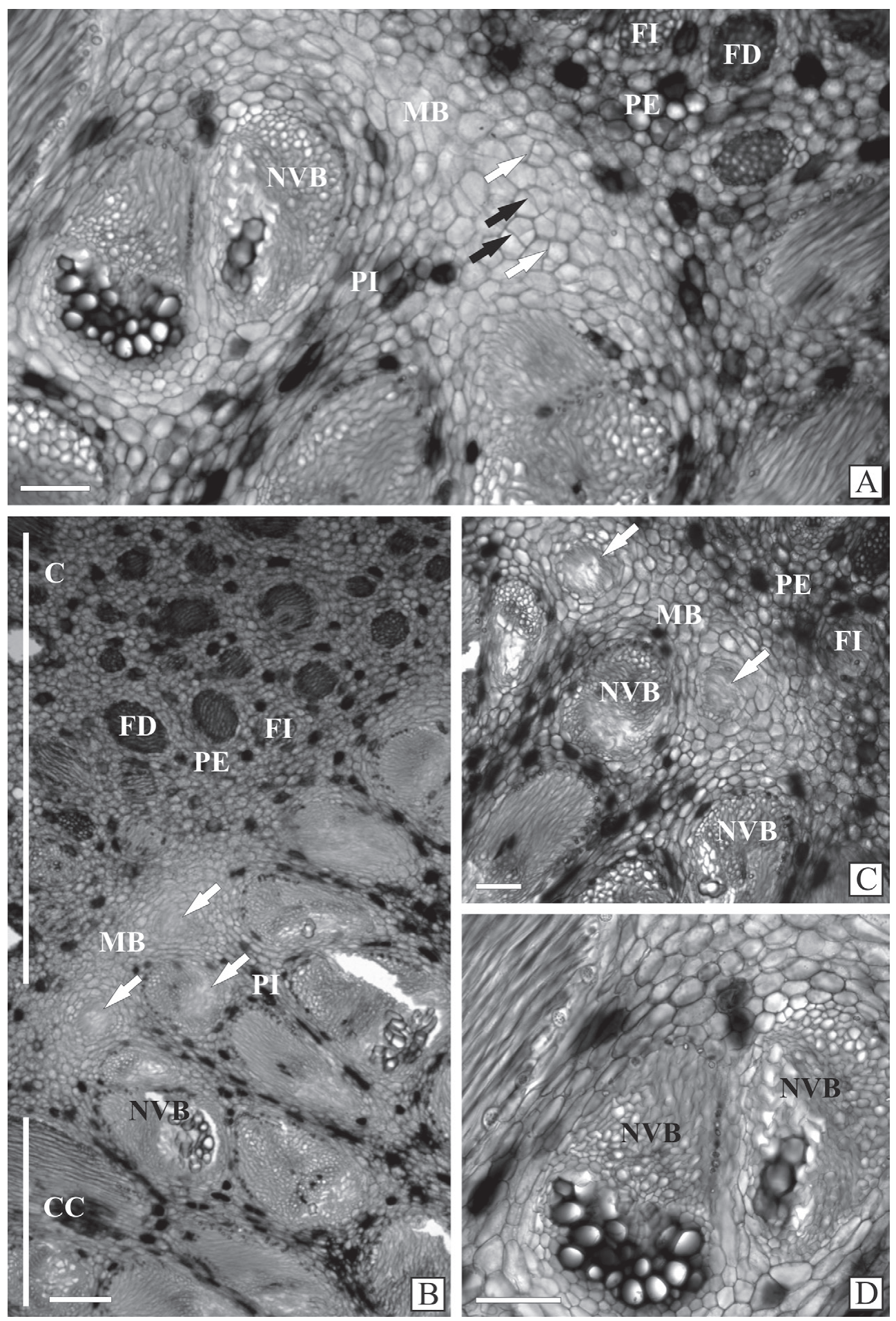

Figure 3 - A - D. Syagrus romanzoffiana. Young plant. Transverse sections of the stem at the interface between the cortex and the central cylinder, showing the meristematic band and its products. A. Detail of the meristematic band showing periclinal divisions (black arrows) and anticlinal divisions (white arrows). B - C. Newly formed vascular bundles appear embedded on the meristematic band (white arrows). D. Detail of two differentiating new vascular bundles. C: cortex, CC: central cylinder, FD: differentiated fiber strand, FI: immature fiber strand, MB: meristematic band, PE: external secondary parenchyma cells, PI: internal secondary parenchyma cells, NVB: new vascular bundle. Scale bars: $100 \mu \mathrm{m}$ (A, C, D); $200 \mu \mathrm{m}$ (B). 

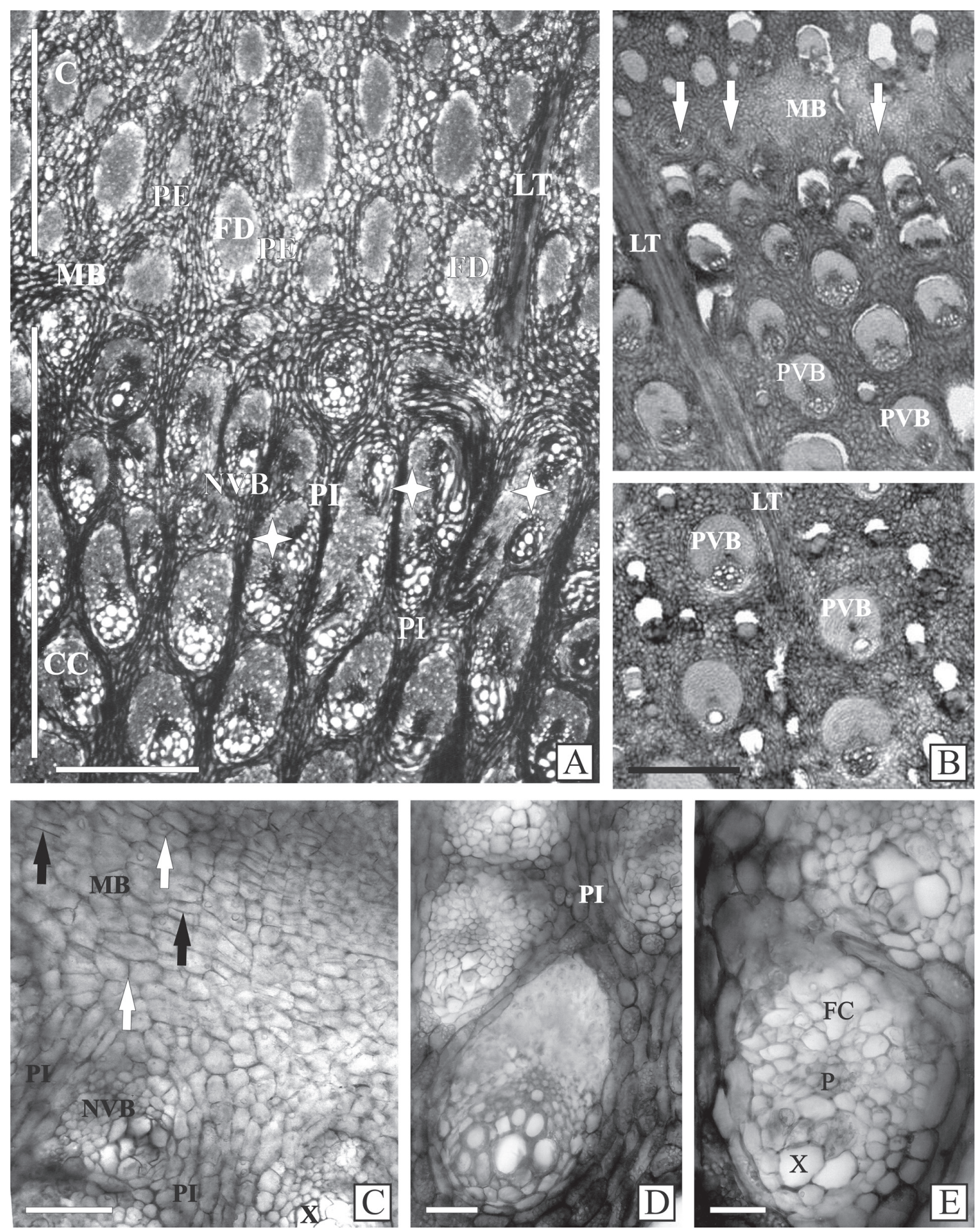

Figure 4 - A - E. Transverse sections. A, C - E. Butia paraguayensis a short stem. B. Syagrus petraea, a subterranean stem. A. Detail of the interface between the cortex and the central cylinder, showing the meristematic band and mature tissues derived from it: new vascular bundle, differentiated fiber strand, secondary external and internal parenchyma. The asterisks show the anastomose of the secondary vascular bundles. B. See the meristematic band with the newly formed secondary vascular bundles (arrows). C. Detail of the meristematic band showing recently divided cells with periclinal walls (black arrows) and anticlinal walls (white arrows). D. Detail of differentiating new vascular bundles. Note that the lower vascular bundle is almost mature. E. Detail of two immature new vascular bundles. AB: axial bundle, FC: fiber cap, FD: differentiated fiber strand, MB: meristematic band, P: immature phloem, PE: secondary external parenchyma cells, PI: secondary internal parenchyma cells, PVB: primary vascular bundle, LT: leaf trace, NVB: new vascular bundle; X: immature xylem. Scale bars: $50 \mu \mathrm{m}$ (A - E). 
apex termed primary thickening meristem (PTM, Helm 1936), but referred as "meristematic cap" by Zimmermann and Tomlinson $(1968,1974)$. But in none of these researches the presence of a meristem was observed, continuous or discontinuous with the PTM, in mature and basal portion of palm stems. For Tomlinson (2006), palms are able to produce trees by several structural and developmental features, all results of the primary growth.

In the four species of palms examined in this study, the meristematic band acts, as mentioned, in a way similar to the secondary thickening meristems in other monocotyledons. Its bidirectional activity forms an external secondary cortex consisting of parenchyma cells and, unlike the other monocotyledons studied thus far, fiber strands. Internally, the meristematic band add new vascular bundles and parenchyma cells to the central cylinder.

The secondary thickening meristem (STM) is found in various species belonging to different families in the order of Asparagales (sensu APG III, Stevens 2008 onwards), and has been very well documented and illustrated in arboreal genera like Cordyline, Dracaena and Yucca. It is characterized as a meristem with bidirectional activity as described by Cheadle (1937) and reaffirmed by DeMason (1983). STM has been observed by various authors in the boundary between cortex and central cylinder adding parenchyma cells to the cortex, and secondary vascular bundles and parenchyma cells to the central cylinder, and can be discontinuous with the primary thickening meristem (Cheadle 1937, Lu and Chiang 1976, Stevenson 1980, Stevenson and Fisher 1980, Diggle and DeMason 1983a, b, DeMason and Wilson 1985). Recently Cattai and Menezes (2010) showed that the secondary thickening meristem has its origin from the pericycle, tissue that for these authors corresponds to the primary thickening meristem mentioned on the literature.

We consider the meristematic band observed on the stem of the four palm species studied to be similar to the secondary thickening meristem as it presents the following characteristics: i) it consists of layers of tangentially flattened, radially aligned meristematic cells that divide primarily periclinally, forming bidirectional secondary tissues; ii) it appears secondarily, i.e., it undergoes meristematic activity in the median and basal stem regions, away from the apical region where the apical and primary thickening meristems are active; iii) it adds a large numbers of vascular bundles to the central cylinder, different from the axial bundles and leaf traces, that compress the new parenchyma cells formed among them, presenting a compact aspect and a structural configuration that is similar to that observed in the stems of arborescent monocotyledons with STM activity, as the Dracaena and Cordyline (Asparagaceae).

The aforementioned characteristics, which were observed in the four species of palm trees studied here, are in accordance with those reported by other workers as follows: 1) STM cells in radial disposition were observed by Stevenson and Fisher (1980), Diggle and DeMason (1983b), Rudall (1984, 1995); 2) STM differentiation in the stem's basal portion is highlighted by Stevenson (1980), who discussed the reports of other workers of an apparent longitudinal discontinuity between the primary thickening meristem (PTM) and the STM; 3) the increase in density of new vascular bundles next to the STM in radial disposition as noted by Stevenson (1980), DeMason (1983), Diggle and DeMason (1983a) and Rudall (1984, 1995).

The evidence presented by Stevenson (1980) that the STM is distinguished from the PTM by its location in the stem was questioned by Diggle and DeMason (1983a), who stated that the PTM and STM can be distinguished only by the type and arrangement of vascular bundles. Our results agree with Diggle and DeMason opinion, as the radial arrangement of the new vascular bundles differs from the scattered primary vascular bundles arrangement throughout the ground tissue. 
The two types of primary vascular bundles observed in the central cylinder of the four species: i) axial bundles, containing only metaxylem, and ii) leaf traces, with both protoxylem and metaxylem, agree with the first observations mentioned for the palm Rhaphis excelsa by Zimmermann and Tomlinson (1965) and Tomlinson and Zimmermann (1966), who analyzed in detail the stems of this species through motion-picture by tracing the path of the vascular bundles through a series of transverse sections. The presence of these two types of primary vascular bundles was confirmed later for other palm species (Zimmermann and Tomlinson 1974, Zimmermann et al. 1982, Zimmermann and Sperry 1983). In 1984, Tomlinson's study of the stem conducting tissues in monocotyledons reiterates that the best definition of leaf trace and axial bundle is functional, taking into account the extent to which protoxylem is differentiated; so the vascular bundle with protoxylem is functionally a leaf trace and in the axial bundle no protoxylem is differentiated. These same differences between the axial bundles and leaf traces also were observed by Menezes (1971), with the analysis of serial sections of the stem of the genus Vellozia (Velloziaceae) and Cattai and Menezes (2010) with their study in the stem of Cordyline fruticosa.

In the species we studied, both primary and new vascular bundles are the same, i.e., they are collateral. Although being amphivasal, the primary and secondary vascular bundles in the stem of Partesonia (Iridaceae) are the same for most of their length (Rudall, 1984). In Cordyline (DeMason and Wilson 1985, Cattai and Menezes 2010) and Yucca (Diggle and DeMason 1983a, b), by contrast, the secondary vascular bundles are amphivasal, whereas the primary bundles are collateral.

As mentioned previously, the literature of the past 100 years characterizes secondary growth in palm stems as diffuse.

However, during a search of the early literature we found that researchers of the early $20^{\text {th }}$ century showed the same secondary growth for palm stems highlighted in this paper, e.g, the presence of a meristematic band responsible for the formation of new vascular bundles and fiber strands. The first one was Zodda, in 1904. In his work entitled "Sull'ispessimento dello stipite di alcune palme" ("About the stem thickening of some palms"), he analyzes the stem of three species of palms: Trachycarpus excelsus, Livistona chinensis and Livistona australis. For the last two species he mentioned the presence of a real secondary meristem. Describing in detail the anatomy of the species 'Livistona chinensis, which has the same anatomy as L. australis, Zodda says on page 536: Coll'aumentata attività neoformativa del parenchima si ha formazione di nuovi fasci, simili nella struttura ai vechi. Questi nuovi fasci si trovano sparsi in mezzo al parenchima neoformato, e sono tanto più giovani quanto più va verso la zona di confine, ove tutti si trovano nella fase procambiale'..: "With the augmented new growth activity, new bundles, similar to the old ones, are formed. These new bundles are scattered in the newly formed parenchyma, and are younger as they are closer to the 'confine zone', where all the elements are in a procambial phase...". The term "confine zone" corresponds to the meristematic parenchyma band that lies between the central cylinder and the cortex. Zodda continues on pages 536-537: Contemporaneamente si ha neoformazione di numerosi cordoni fibrosi e di scarsissimi fasci, i quali però sono più piccoli di quelli del cilindro centrale (vedi fig. 3). Cordoni e fasci si presentano tanto più giovani quanto più si procede verso la zona di confine, ove si trovano tutti nello stato procambiale. Il processo neoformativo nello strato fibroso procede adunque in senso centripeto, opposto cioè a quella del cilindro centrale e la zona di confine fra $i$ due strati se ne mostra la sede., whose translation is: "Contemporaneously, the new-formation of numerous fiber strands and scarce bundles occur, the former much smaller than those of the central cylinder (see fig. 3). Strands and 
bundles are smaller as they are closer to the confine zone in which all the elements are in procambial phase. The newly formed fiber layer proceeds in a centripetal mode, opposed to that seen in the central cylinder and it is in between them that the confine zone is found." Finally, on page 537 Zodda brings the synthesis of the results: Fasci e cordoni neoformati, come s'è visto, prendono origine in seno ad elementi parenchimatici anch'essi neoformati., which means: "Newly formed bundles and strands, as seen, have their origin in the middle of the parenchyma cells, those likewise just newly formed."

Furthermore, two years later, in 1906, Strasburger brings to surface his data with the species Washingtonia filifera. In his work, he mentions he became interested in the species because his Italian colleague Borzi commented, in 1896, about his findings in relation to growth in thickness in palms, which presented a similar thickening ring to those of the arboreal Dracaena, especially the thicker ones. Still according to Strasburger, Borzi wrote to him in 1901 saying that Washingtonia, Acanthophenix cunninghami, Kentia and Ptychosperma have similar growth to that of Yucca and Aloe. The Italian colleague is kind enough to send him two histological slides of Washingtonia filifera and one of Kentia forsteriana to show what he considered similar secondary growth to Dracaena's. Strasburger (1906) managed to obtain a $10 \mathrm{ft}$. tall specimen of Washingtonia filifera, which he analyzed at various distances from apex to base, i.e., at various stages of development. He observed that at several locations the interface between cortex and central cylinder can be discerned, and that at this interface a layer of cells, which he called pericycle, occurs in various stages of development, from top to bottom of the stem. Strasburger observed that this meristem, has bidirectional meristematic activity, forming vascular bundles to the inside, i.e., towards the central cylinder, and cortical cells and fiber strands to the outside. According to Strasburger, this bidirectional activity is similar to that of a cambium. Strasburger concluded, however, that Washingtonia filifera does not undergo secondary growth per se because he did not observe continuity in the meristematic band, i.e., there was no "Kambiumring in Pericykel" - cambium ring in pericycle - as in Dracaena.

A year later, Baccarini (1907) resumed Zodda's (1904) and Strasburger's (1906) work and commented on it. Baccarini criticized Strasburger for not reading Zodda's 1904 article, as follows (Baccarini 1907, page 56): Il lavoro dello Strassburger è senza alcun dubbio interessante e diverrà fondamentale, non fosse altro per la grande autorità del nome, e fará passare in giudicato la cosa: tuttavia debbo con piacere rimarcare un fatto: che cioè $i$ fenomeni osservati dallo Strassburger erano già stati nel loro complesso osservati dal Zodda da qualche anno, e con dispiacere rimarcarne un altro; che questo lavoro del Zodda non è affatto citato., whose translation is: "Strasburger's work is with no doubts interesting and will be crucial, thanks to his fame......nonetheless with pleasure I have to remark one fact: that is, the phenomena observed by Strasburger had already been described in all their complexity by Zodda some years ago; and it is with displeasure that I will remark something else; that the work of Zodda has not been cited at all".

From this history one can conclude that Borzi (apud Strasburger 1906), Zodda (1904) and Strasburger (1906), observed a growth in thickness in palms by the activity of a meristematic band with neo-formation tissues. Zodda (1904) and Strasburger (1906) described in detail the presence of this meristematic band with a bidirectional activity at the interface between cortex and central cylinder, a band that formed new vascular bundles towards the central cylinder and fiber bundles and parenchyma cells towards the cortex. Strasburger did not consider the species he studied to exhibit secondary growth similar to that found in Dracaena as Borzi had suggested, but 
rather growth emanating from an active pericycle. Zodda (1904) on the other hand considered this bidirectional meristem a secondary one.

Our observations are similar to those reported by Zodda (1904) and Strasburger (1906). It shows that the diffuse secondary thickening is not the only mechanism of secondary growth in palms and that the presence of a meristem band in the stems of palms merits further studies to better understand their origin and relation with the pericycle, primary and/or secondary thickening.

\section{ACKNOWLEDGMENTS}

The authors are thankful to Amauri Marcato, Milton Groppo Junior and Renato Mello-Silva for help with field collection and plant identification, Antonio Carlos Franco Barbosa for help with anatomical procedures, Maíra Tavares for slide mounting and old bibliographic findings, Nanuza Luiza de Menezes for valuable scientific inputs in the anatomical observations, Gertrudes Baer Angyalossy for German translation, Marcelo Pace for comments on the manuscript and Italian translation, and both the Fundação de Amparo à Pesquisa do Estado de São Paulo (FAPESP: 00/08182-0) and the Conselho Nacional de Desenvolvimento Científico e Tecnológico (CNPq: 3088893/2006-9) Brazilian Government, for financial support.

\section{RESUMO}

Diferentemente de outras monocotiledôneas arbóreas, o crescimento secundário em palmeiras é descrito desde os últimos cem anos como sendo do tipo difuso, que é caracterizado pelo alargamento e divisões aleatórias de células parenquimáticas. Entretanto, alguns trabalhos no início do século XX mencionam a presença de um meristema secundário nos caules das palmeiras, mas essa informação foi esquecida desde então. Visando retomar essa questão, analisamos o caule de quatro espécies de palmeiras, com o objetivo de entender a possível presença de tal crescimento secundário. Observamos que uma faixa meristemática ocorre entre o córtex e o cilindro central e dá origem internamente a novos feixes vasculares e parênquima, e externamente a parênquima e cordões de fibras. Essa faixa meristemática surge secundariamente, isto é, inicia sua atividade meristemática nas regiões medianas e basais do caule, muito afastadas da região apical caulinar. Tais resultados confirmam a presença de uma faixa meristemática ativa e pode ser mais comum do que se acredita atualmente, mas difícil de ser detectada em certas palmeiras por ser restrita a regiões específicas de seus caules. Concluindo, demonstra-se nesse trabalho que o crescimento em espessura do tipo difuso não é o único mecanismo do crescimento secundário em palmeiras e que a presença de uma faixa meristemática nos caules das palmeiras merece cuidadosa reconsideração.

Palavras-chave: caule aéreo, faixa meristemática, palmeiras, crescimento secundário, anatomia caulinar, caule subterrâneo.

\section{REFERENCES}

BACCARINI P. 1907. Attorno all accrescimento in spessore dei fusti delle Palme. Nuovo Giornale Botânico Italiano 14: 56-69.

Baker JW, Savolainen V, Asmussen-Lange CB, Chase MW, Dransfield J, Forest F, Harley MH, UhL NW AND Wilkinson M. 2009. Complete Generic-Level Phylogenetic Analyses of Palms (Arecaceae) with Comparisons of Supertree and Supermatrix Approaches. Syst Biol 58: 240-256.

BARbosa ACF, PACE MR, WitovisK L AND ANGyalossy V. 2010. A new method to obtain good anatomical slides of heterogeneous plant parts. IAWA J 31: 373-383.

BERLYN GP AND MIKSCHE JP. 1976. Botanical microtechnique and cytochemistry. The Iowa State Press, Ames.

Cattai MB And Menezes NL. 2010. Primary and secondary thickening in the stem of Cordyline fruticosa (Agavaceae). An Acad Bras Cienc 82: 653-662.

CHEADLE VI. 1937. Secondary growth by means of a thickening ring in certain monocotyledons. Bot Gaz 98: 535-555.

DEMASON DA. 1983. The primary thickening meristem: Definition and function in monocotyledons. Am J Bot 70: 955-962.

DEMASON DA AND WILSON MA. 1985. The continuity of primary and secondary growth in Cordyline terminalis (Agavaceae). Can J Bot 63: 1907-1912.

DigGLE PK AND DEMASON DA. 1983a. The relationship between the primary thickening meristem and the secondary thickening meristem in Yucca whipplei Torr. I. Histology of the mature vegetative stem. Am J Bot 70: 1195-1204. 
DigGLE PK AND DeMAson DA. 1983b. The relationship between the primary thickening meristem and the secondary thickening meristem in Yucca whipplei Torr. II. Ontogenetic relationship within the vegetative stem. Am J Bot 70: 1205-1216.

DRANSFIELD J, UHL NW, ASMUSSEN CB, BAKER WJ, HARLEY MM AND LEWIS CE. 2005. A new phylogenetic classification of the palm family, Arecaceae. Kew Bull 60: $559-569$.

Gerlach D. 1984. Botanische Mikrotechnik, 3d ed., Georg Thieme Verlag, Stuttgart.

Helm J. 1936. Das Erstarkungswachstum der Palmen und einiger anderer Monokotylen, zugleich ein Beitrag zur Frage des Erstarkungswachstums de Monokotylen überhaupt. Planta 26: 319-364.

Kraus JE, Sousa HC, Resende MH, Castro NM, Vecchi C AND LUQUE R. 1998. Astra blue and basic fuchsin double staining of plant material. Biotech Histochem 73: 235-243.

LU C-Y AND CHIANG S-HT. 1976. Lateral thickening in the stem of Agave rigida Mill. and Aloe vera L. Taiwania 21: 204-219.

Menezes NL. 1971. Traqueídes de transfusão no gênero Vellozia Vand. Cien Cult 23: 389-409.

RUDALL P. 1984. Taxonomic and evolutionary implications of rhizome structure and secondary thickening in Iridaceae. Bot Gaz 145: 524-534.

RUDALL P. 1995. New records of secondary thickening in monocotyledons. IAWA J 16: 261-268.

SCHOUTE JC. 1912. Über das Dickenwachstum der Palmen. Annales du Jardin Botanique de Buiternzorg(Sér.2) 11: $1-209$.

SteVEns PF. 2008. Angiosperm Phylogeny Website http:// www.mobot.org/MOBOT/research/APweb/.

STEVENSON DW. 1980. Radial growth in Beaucarnea recurvata. Am J Bot 67: 476-489.

STEVENSON DW AND FisheR JB. 1980. The developmental relationship between primary and secondary thickening growth in Cordyline (Agavaceae). Bot Gaz 141: 264-268.

STRASBURGER E. 1906. Über die Verdickungsweise der Stämme von Palmen und Schraubenbäumen. In: Pfeffer W and Strasburger E (Eds), Jahrbücher für wissenschaftliche Botanik. Gebrüder Borntraeger, Leipzig, p. 580-628.

TOMLINSON PB. 1960. Essays on the morphology of palms. II. The early growth of the palm. Principes 4: 140-143.
TOMLinson PB. 1961. Anatomy of the Monocotyledons II Palmae. Clarendon Press, Oxford.

TOMLINSON PB. 1984. Development on the stem conducting tissues in monocotyledons. Contemporary Problems in Plant Anatomy. Academic Press, p. 1-50.

TomLinson PB. 1990. The Structural Biology of Palms. Clarendon Press, Oxford.

TomLinson PB. 2006. The uniqueness of palms. Bot J Linn Soc 151: 5-14.

TOMLINSON PB, Fisher JB, SPANGLER RE AND RicheR RA. 2001. Stem vascular architecture in the rattan palm Calamus (Arecaceae-Calamoideae-Calaminae). Am J Bot 88: 797-809.

TOMLINSON PB AND SPANGLER RE. 2002. Developmental features of the discontinuous stem vascular system in the rattan palm Calamus (Arecaceae-Calaminae). Am J Bot 89: 1128-1141.

TOMLINSON PB AND ZIMMERMANN MH. 1966. Anatomy of the palm Rhapis excelsa. II. Rhizome. J Arn Arb 47: 248-261.

TOMLINSON PB AND ZIMMERNANN MH. 1967. The "Wood" of Monocotyledons. IAWA Bull 2: 4-22.

WATERHOUSE JT AND QUINN CJ. 1978. Growth patterns in the stem of the palm Archontophoenix cunninghamiana. Bot J Linn Soc 77: 73-93.

Zimmermann MH, MCCUE KF AND SPERRY J. 1982. Anatomy of the palm Rhaphis excelsa. VIII. Vessel network and vessel-length distribution in the stem. J Arn Arb 63: 83-95.

ZIMMERMANN MH AND SPERRY J. 1983. Anatomy of the palm Rhaphis excelsa. IX. Xylem structure of the leaf insertion. J Arn Arb 64: 599-609.

ZIMMERMANN MH AND TOMLINSON PB. 1965. Anatomy of the palm Rhapis excelsa. I. Mature vegetative axis. J Arn Arb 46: 160-178.

ZIMMERMANN MH AND TOMLINSON PB. 1967. Anatomy of the palm Rhapis excelsa. IV. Vascular development in apex of vegetative aerial axes and rhizome. J Arn Arb 48: 122-142.

ZIMMERMANN MH AND TOMLINSON PB. 1968. Vascular construction and development in the aerial stem of Prionium (Juncaceae) Am J Bot 55: 1100-1109.

ZIMMERMANN MH AND TOMLINSON PB. 1974. Vascular patterns in palm stems: variations of the Rhaphis principle. J Arn Arb 55: 402-424.

ZodDA G. 1904. Sull' ispessimento dello stipite di alcune palme. Malpighia 18: 512-545. 